\title{
Bulk Physiognomies and Sara Constituents of Bituminous Sands from Ondo State, Nigeria
}

\author{
Victor-Oji CO*, Osuji LC and Onojake MC
}

Department of Pure and Industrial Chemistry, Petroleum Chemistry Research Group, University of Port Harcourt, Choba, Port Harcourt, Nigeria

\begin{abstract}
Bituminous sands obtained from six different locations in Ondo State, Nigeria were analysed. Physicochemical parameters were studied using American Standard Testing and Materials (ASTM) procedures and analysis of hydrocarbon and non-hydrocarbon fractions using Ultraviolet Visible Spectrophotometer were undertaken. Results obtained show: density $\left(0.877-0.884 \mathrm{~g} / \mathrm{cm}^{3}\right)$; specific gravity $(0.878-0.886)$; API gravity $\left(28.133^{\circ} \mathrm{API}\right.$ to $\left.29.531^{\circ} \mathrm{API}\right)$; kinematic viscosity $(0.440 \mathrm{cSt}$ to $0.550 \mathrm{cSt})$; dynamic viscosity $(0.290-0.360)$; cloud point $\left(-15^{\circ} \mathrm{C}\right.$ to $\left.-2^{\circ} \mathrm{C}\right)$; moisture content ( $775 \mathrm{ppm}$ to $1761 \mathrm{ppm})$; gum content $(605-1895 \mathrm{mg} / 100 \mathrm{ml})$ and pour point of $<-34^{\circ} \mathrm{C}$. Result of the Saturates, Aromatics, Resins and Asphaltene (SARA) analysis revealed; saturates; $44.139 \%$ to $69.436 \%$, aromatics; $21.778 \%$ to $44.949 \%$, resins; $11.067 \%$ to $28.369 \%$ and asphaltenes; $8.634 \%$ to $29.278 \%$. They suggest that these bituminous sands have similar characteristics, can be classified as medium heavy oils on the API gravity scale, high in saturate hydrocarbons and low in asphaltene content which indicates their high hydrocarbon potential.
\end{abstract}

Keywords: Bituminous sands; Physiochemical; SARA; ASTM

\section{Introduction}

The recognition of dwindling conventional world oil reserves has necessitated the need for alternative sources of energy. Thus, a ready alternative to the conventional crude oil are bituminous sands which are abundant and vastly unexplored [1]. Bituminous sands are composed of heavy oils and clays, rich in mineral and water. They are naturally occurring mixtures which contain about $10 \%$ bitumen, $5 \%$ water and $85 \%$ solids, small amount of heavy metals and other contaminants [2]. The Nigerian bituminous sand deposits are sited within the confines of the Eastern Margin of Dahomey basin which lies within a depobelt cutting across three major states which include: Ondo, Ogun, Edo and parts of Lagos, in minable commercial quantities with a combined reserve of about 14.86 billion barrels. Studies have confirmed that Nigerian bituminous sands are important alternative energy sources and hydrocarbon raw material for the petrochemical industry [3]. Physicochemical characterisation and SARA analysis has been undertaken to inspect the suitability of bituminous sands from Ondo State and decipher its suitability for particular applications in the petroleum and petrochemical industry by prospective users.

\section{Experimental}

\section{Sample description and preparation}

The bituminous sands used in this study were sampled from six locations within Irele local government area namely; Agbabu (AB), AyeRailhead (AY), Idiobilayo (ID), Ilubirin (IL), Ladawo (LA) and Ludasa (LU) in Ondo State, South-Western, Nigeria. The research study area lies between longitudes $4^{\circ} 52^{\prime}$ and $4^{\circ} 55^{\prime} \mathrm{E}$ and between latitudes $6^{\circ} 27^{\prime}$ and $6^{\circ} 35^{\prime} \mathrm{N}$. Several schools of thought have highlighted the origin/ occurrence of bituminous sands deposit in Nigeria since its discovery [4]. One of them suggests that petroleum hydrocarbons possibly migrated from the Niger Delta Basin via faults or interconnected sand bodies to the Eastern region of Dahomey basin. The Dahomey Basin which forms part of the West-African pericretonic basin advanced during the initiation of the rifting linked with the opening of the Gulf of Guinea, in Early Cretaceous to Late Jurassic age [5-8]. The research study area belongs to Ise Formation of Cretaceous Abeokuta group which is the oldest group of basin sediment unconformably overlying the basement complex (Figure 1).

\section{Analysis of saturates, aromatics, resins and asphaltenes}

The experimental procedures involved in Saturates, Aromatics, Resins, and Asphaltenes determination includes the following.

Extraction and de-asphalting of Bituminous Sands: A modified ASTM D2007 technique was employed as follows; $200 \mathrm{ml}$ of a 1:1 solvent mixture ratio of $\mathrm{n}$-heptane and toluene was introduced to twenty grams $(20 \mathrm{~g})$ of bituminous sands in an Erlenmeyer flask, refluxed at $80^{\circ} \mathrm{C}$ for 6 hours, cooled and the extract decanted. The residue left was rinsed using $\mathrm{n}$-toluene/heptane into the flask alongside the bituminous sand bitumen extract. After solvent recovery with rotary evaporator, pure residue was taken as asphaltene and the extract as raffinate.

Fractionation of de-asphalted raffinate by column chromatography: The fractionation column was carefully packed with $\mathrm{n}$-heptane pre-wetted activated alumina. Twenty grams $(20 \mathrm{~g})$ of raffinate, i.e., the de-asphalted component, was added after dissolving in $100 \mathrm{ml}$ of $\mathrm{n}$-heptane. Hydrocarbon components (i.e., Saturates and Aromatics) being less polar were initially eluted with continuous addition of $n$-heptane until it becomes colourless [9].

Ultraviolet visible spectroscopy determination of hydrocarbon components in the isolated fractions: An LF-112161 model ultraviolet visible spectrophotometer was used to measure relative abundance after resolving the hydrocarbon fractions into Saturates, Aromatics, Resins,

"Corresponding author: Victor-Oji CO, Department of Pure and Industrial Chemistry, Petroleum Chemistry Research Group, University of Port Harcourt, Choba, Port Harcourt, Nigeria, Tel: 08059307001; E-mail: cynthia.anyanwu@uniport.edu.ng

Received August 07, 2017; Accepted August 31, 2017; Published September 07,2017

Citation: Victor-Oji CO, Osuji LC, Onojake MC (2017) Bulk Physiognomies and Sara Constituents of Bituminous Sands from Ondo State, Nigeria. J Pet Environ Biotechnol 8: 338. doi: 10.4172/2157-7463.1000338

Copyright: ( 2017 Victor-Oji CO et al. This is an open-access article distributed under the terms of the Creative Commons Attribution License, which permits unrestricted use, distribution, and reproduction in any medium, provided the original author and source are credited. 


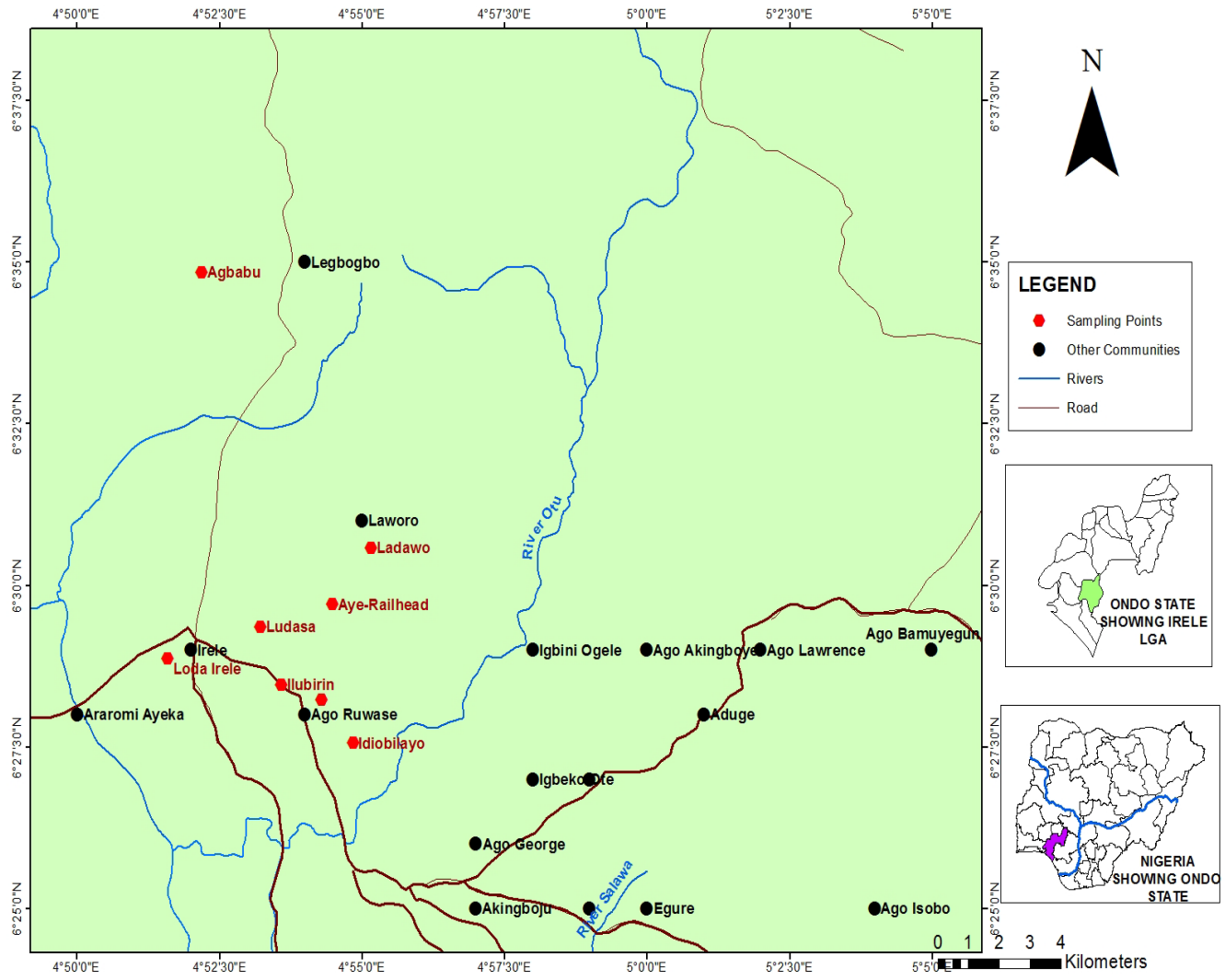

Figure 1: Topographic map showing sample locations and study area.

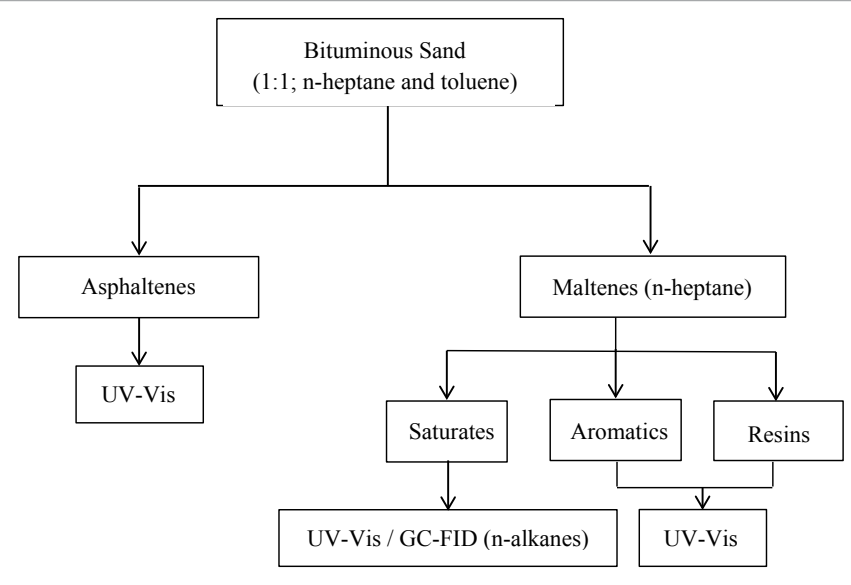

Figure 2: Modified ASTM D2007 SARA fractionation procedure.

and Asphaltenes (SARA). Concentrations of analysed components are read out in percentage by weight (wt\%) as schematically outlined in Figure 2.

\section{Physicochemical analysis}

The bituminous sands were prepared by dissolution in 250 $\mathrm{ml}$ petroleum ether. The resultant solution was filtered using a Whattman filter paper into a $120-\mathrm{ml}$ sample bottle for further analysis. Physicochemical parameters such as density, relative density, API gravity, kinematic viscosity, cloud point, pour point, moisture and gum content were analysed using appropriate American Standards Testing and Materials (ASTM) methods.

\section{Results and Discussion}

\section{Saturates, aromatics, resins and asphaltenes components}

The observed results in Table 1 show that samples LA and ID have high and low percentage saturates, aromatics, asphaltene, resins compositions respectively amongst the studied bituminous sand samples. The observed trend for the SARA percentage composition is; Saturates $>$ Aromatics $>$ Resins $>$ Asphaltene in Aye-Railhead (AY), Ludasa (LU), Agbabu (AB), Ilubirin (IL) and Idiobilayo (ID) bituminous sand samples with a slightly different trend observed; Saturates > Aromatics > Asphaltene > Resins in Ladawo (LA) bituminous sand sample. The analyses show that the bituminous sand samples are rich in saturates and aromatics but have low asphaltene and resin content (Figure 3). Low percentage composition of asphaltenes confirm their terrestrial origin, although part of the asphaltene fractions could have been lost during migration which may also suggest that they may have been derived from thermally matured and non-biodegraded oil sand rocks [10].

\section{Physicochemical analysis}

Results obtained for the physicochemical parameters of the studied bituminous sands in Table 2 suggest that they are medium heavy oils with the API value range of; $28.133^{\circ} \mathrm{API}$ to $29.531^{\circ} \mathrm{API}$ (medium heavy oil range; $22 \leq^{\circ} \mathrm{API}<31$ ), they have high paraffinicity and can compare with acceptable bitumen qualities around the world [11].

Specific gravity (SG) and API gravity: Specific and API gravity are vital in the initial selection and identification of biologically linked rock oils. SG provides an unsure measure of the quantity of lighter hydrocarbons existing in an oil sample. Low SG and high API values 
Citation: Victor-Oji CO, Osuji LC, Onojake MC (2017) Bulk Physiognomies and Sara Constituents of Bituminous Sands from Ondo State, Nigeria. J Pet Environ Biotechnol 8: 338. doi: 10.4172/2157-7463.1000338

Page 3 of 4

\begin{tabular}{|c|c|c|c|c|c|c|c|}
\hline \multirow{2}{*}{ SARA Components } & \multicolumn{7}{|c|}{ Results obtained in wt \% } \\
\hline & LU & AB & IL & ID & AY & LA & AVERAGE \\
\hline Saturates & 56.64 & 48.39 & 52.41 & 44.14 & 64.79 & 69.44 & 55.97 \\
\hline Aromatics & 35.85 & 27.35 & 33.64 & 21.78 & 42.63 & 44.95 & 34.37 \\
\hline Resins & 19.17 & 15.78 & 21.9 & 11.07 & 24.61 & 28.37 & 20.15 \\
\hline Asphaltenes & 16.37 & 11.17 & 14.89 & 8.63 & 19.72 & 29.28 & 16.68 \\
\hline
\end{tabular}

Table 1: SARA data of the bituminous sand samples.

\begin{tabular}{|c|c|c|c|c|c|c|c|c|}
\hline Parameters & Methods & Units & LU & $A B$ & IL & ID & AY & LA \\
\hline Density at $15^{\circ} \mathrm{C}$ & ASTM D-4052 & $\mathrm{g} / \mathrm{cm} 3$ & 0.8848 & 0.8791 & 0.8772 & 0.8845 & 0.8786 & 0.8797 \\
\hline Specific gravity at $60^{\circ} \mathrm{F}$ & - & - & 0.8864 & 0.8802 & 0.8787 & 0.8859 & 0.8799 & 0.881 \\
\hline API gravity & - & $\circ$ & 28.133 & 29.259 & 29.531 & 28.23 & 29.308 & 29.111 \\
\hline Kinematic viscosity at $40^{\circ} \mathrm{C}$ & ASTM D-445 & -Cst & 0.55 & 0.46 & 0.47 & 0.46 & 0.45 & 0.44 \\
\hline Dynamic viscosity & ASTM D-2162 & - & 0.36 & 0.3 & 0.31 & 0.3 & 0.29 & 0.29 \\
\hline Cloud point & ASTM D-2500 & ${ }^{\circ} \mathrm{C}$ & -10 & -15 & -8 & -5 & -2 & -3 \\
\hline Pour point & ASTM D-97 & ${ }^{\circ} \mathrm{C}$ & $<-34$ & $<-34$ & $<-34$ & $<-34$ & $<-34$ & $<-34$ \\
\hline \multirow{3}{*}{ Moisture content } & ASTM D-1744, & ppm & - & - & - & - & - & - \\
\hline & ASTM D-1364, & - & - & - & - & - & - & - \\
\hline & UOP 213 & - & 1761 & 904 & 775 & 833 & 1009 & 820 \\
\hline Gum content & ASTM D-381 & $\mathrm{mg} / 100 \mathrm{ml}$ & 1517 & 605 & 1614 & 726 & 1546 & 1895 \\
\hline
\end{tabular}

AB: Agbabu; AY: Aye-Railhead; ID: Idiobilayo; IL: Ilubirin; LA: Ladawo; LU: Ludasa

Table 2: Physicochemical properties of the bituminous sand samples.

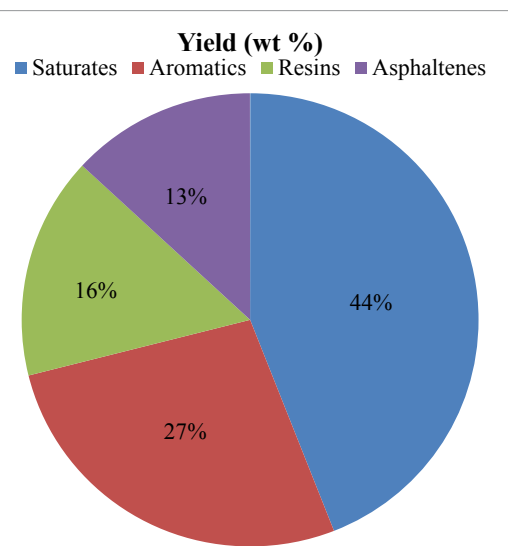

Figure 3: SARA percentage yield of the bituminous sands.

give higher yields of light fractions on distillation of the oils. SG values of the bituminous sands range from (0.879-0.886) which compare favourably with values (0.910-1.013) obtained at another location in Ondo state, suggesting that the bituminous sand is of good quality [12]. Low API is generally connected to bio-degraded oils or not fully formed sulphur-rich oils, while samples with moderate to high oil API gravities. It shows that they might have developed from clay rich source rocks [13-15]. From the results of the analysis, it can be said that Nigerian bituminous sands would produce high quality lube oil for domestic use as well as export.

Kinematic viscosity: Kinematic viscosity is the ratio of momentum transfer to momentum storage. It is a transport property used for characterization of hydrocarbons. Many petroleum products are lubricants in machines or equipment applications. The good functioning of machines or equipment depends upon the viscosity of the lubricant utilized. The kinematic viscosity helps predict physical properties, develop the process design, and design the equipment, storage and transport facilities. Kinematic viscosity of the bituminous sands is low, which is anticipated as the bituminous sand is categorized as medium heavy oil.
Cloud point: This is the lowest temperature at which wax crystals begin to form in heavy hydrocarbon fractions by a gradual cooling under standard condition. Sometimes, the heavy hydrocarbons and oils, especially waxes, tar, bitumen and asphalt, lose their fluidity and turn into solid. This solidification causes some serious problems in process, storage and transportation of hydrocarbons. Therefore, by considering safety its knowledge is substantive. The value for the cloud point for the samples is $<-34^{\circ} \mathrm{C}$ for most bitumen of good grade. It was detected that bituminous sands under investigation have high wax content [16,17].

Existent gum: This is a measurement of oxidation products formed in the oil which cannot be evaporated under regulated conditions of temperature and air or steam flow. The principle behind its measurement involves unsaturated hydrocarbons combining themselves with oxygen to form a non-volatile sticky substance called gum. The value for the studied samples ranged from $605.000 \mathrm{mg} / 100 \mathrm{ml}$ to $1895.000 \mathrm{mg} / 100$ $\mathrm{ml}$, which implies the presence of few unsaturated hydrocarbons.

Moisture content: Moisture in crude oils is a contamination and is not energy yielding. The percentage of water in the fuel can be converted into a corresponding energy loss for the customer. The average moisture content of the bituminous sand samples is $16.67 \%$. The result, $15.14 \%$, shows a minor dissimilarity in contrast to that of some workers whose moisture content range in the bituminous sand bitumen separated from the Agbabu sample [9]. This infers that they have high quality considering their low water content.

\section{Conclusion}

Data from the physicochemical and SARA analyses have been employed to evaluate bituminous sand samples from six deposits in Ondo state. These observations on the studied samples indicate that these bituminous sands possess good quality indices and can compare with bituminous sands of good qualities around the world as portrayed by their physicochemical parameters and SARA compositions. The hydrocarbon content of bituminous sands is significantly higher compared to non-hydrocarbon content (asphaltenes and resins) which suggests that bitumen extracted from these sample locations will be of high quality as they are mostly paraffinic. I recommend that more 
Citation: Victor-Oji CO, Osuji LC, Onojake MC (2017) Bulk Physiognomies and Sara Constituents of Bituminous Sands from Ondo State, Nigeria. J Pet Environ Biotechnol 8: 338. doi: 10.4172/2157-7463.1000338

research should be done on the viscosities of these oils as it might pose a big problem for refining processes when used as feed stocks. These bituminous sands are vast pools of petrochemical feed which is vital for the development of the chemical industry, if utilized appropriately. This research has shed more light on the Nigerian bituminous sands and apart from its use for road construction (i.e. bituminous sand extract; bitumen), lube oil and other petrochemicals can be distilled from these heavy oil deposits thus utilizing its resource maximally. These bituminous sands are vast pools of petrochemical feed which is vital for the development of the chemical industry, if utilized appropriately.

\section{Acknowledgement}

The authors acknowledge the effort of Department of Petroleum Resources of Nigeria (DPR) for granting us access to bituminous sands sample locations, Eleme Petrochemicals and Jaros Inspection Services Ltd, Port Harcourt. We are also grateful to Mr. Frank Oteiva and Mr. Tunde for the help in the sample analyses.

\section{References}

1. Spirov P, Rudyk SN, Tyrovolas A, Jimoh I (2013) The bitumen extraction from Nigerian tar sand using dense carbon dioxide. Chemical Eng Trans 32: 283-288

2. Adedimila AS (1987) Okitipupa bituminous sands: New construction materials for flexible pavements? The Nig Eng 22: 1-14.

3. Ukwuoma O (1999) Study of composition of Nigerian tar sand bitumen. Pet Sci Technol 17: 57-65.

4. Akintola Al, Ikhane PR, Adeola O (2013) Heavy mineral and grain size characterization of bitumen seeps exposed at Ogbere, South Western. Nigeria. International Research Journal of Geology and Mining 3: 82-101.

5. Burke K, Dessauvagie TFJ, Whiteman AJ (1971) Opening of the Gulf of Guinea and Geological history of the benue depression and Niger delta. Nature 233: 51-55
6. Klemme HD (1975) Geothermal gradients, heat flow and hydrocarbon recovery Petroleum and Global Tectonics. Fischer AG, Judson S (eds) Princeton University Press, Princeton, New Jersey, USA. pp. 251-304.

7. Whiteman AJ, Dessauvagie TFJ (1982) African Geology. Ibadan: University of Ibadan Press, Nigeria.

8. Kingston DR, Dishroon CP, Williams PA (1983) Global basin classification system. American Association of Petroleum Geologists Bulletin 67: 2175-2193.

9. Adebiyi FM, Omode AA (2007) Organic, chemical and elemental characterization of components of Nigerian bituminous sands bitumen. Energy Sources Part A 29: 669-676.

10. Frankenberger A, Brooks RR, Varela-Alvarez $H$, Collen JD, Filby $R H$, et al (1994) Classification of some New Zealand crude oils and condensates by means of their trace element contents. App Geochemistry 9: 65-71.

11. Odebunmi EO, Ogunsakin EA, Ilukhor PEP (2002) Characterization of crude oils and Petroleum products (I): Elution liquid chromatographic separation and gas chromatographic analysis of crude oils and petroleum products. Bull Chem Soc Ethiop 16: 115-132.

12. Adebayo EA (2004) Extraction and characterization of Bitumen from Ondo state Tar sand. In proceedings of the 8th National Engineering conference of Kaduna Polytechnic. p. 82-88.

13. Hedberg HD (1968) Significance of high-wax oil with respect to genesis of petroleum. American Association of Petroleum Geologists Bulletin 52: 736-750.

14. Gransch JA, Posthuma J (1973) On the origin of sulphur in crudes. Adv Org Geochem 727-739.

15. Baskin DK, Peters KE (1992) Early generation characteristics of a sulphur-rich Monterey kerogen. American Association of Petroleum Geologists 76: 1-13.

16. Mumah SN, Muktar S (2001) Improving road pavements with natural rubber Journal of Engineering Technology and Industrial Applications 1: 208-220.

17. Riazi MR (2005) Characterization and Properties of Petroleum Fractions. American Society for Testing and Materials International. 